\title{
ISOLASI MIKROBA PENGHASIL ANTIBIOTIK DARI TANAH PETERNAKAN AYAM KECAMATAN PATTALLASSANG KABUPATEN GOWA
}

\author{
Gemy Nastity Handayany* \\ *Jurusan Farmasi Fakultas Kedokteran dan Ilmu Kesehatan \\ Universitas Islam Negeri (UIN) Alauddin Makassar \\ E-mail : gemynastity75@gmail.com
}

\begin{abstract}
Abstrak: Telah dilakukan penelitian isolasi mikroba penghasil Antibiotika dari tanah peternakan ayam kecamatan pattallassang kabupaten gowa. Penelitian ini bertujuan untuk memperoleh isolat mikroba penghasil Antibiotika yang dapat menghambat mikroba uji dari tanah peternakan ayam. Tahap pertama isolasi mikroba dilakukan pengenceran $10^{-1}$ hingga $10^{-5}$ dengan menggunakan metode tuang pada medium Nutrient Agar (NA) dan Potato Dextrosa Agar (PDA), kemudian difermentasi menggunakan medium Maltosa Yeast Broth (MYB). Aktivitasnya diujikan menggunakan metode difusi agar dalam medium Nutrient Agar (GNA) terhadap mikroba uji. Hasil isolasi didapatkan 3 isolat Bakteri dan 4 isolat jamur dan semua isolat memberikan aktivitas : untuk Bakteri uji Escherichia coli dihambat oleh isolat Jamur I dan Jamur II. Untuk Bakteri uji Staphylococcus aureus dihambat oleh isolat Bakteri III dan Jamur I. Untuk Bakteri uji Streptococcus mutans dihambat oleh isolat Jamur I dan Jamur IV. Untuk Bakteri uji Vibrio sp dimana isolat tidak ada yang menghambat. Untuk Bakteri uji Bacillus subtilis dihambat oleh isolat Bakteri II serta Jamur I dan Jamur II. Untuk Bakteri uji Pseudomonas auroginosa dihambat oleh isolat Bakteri III serta Jamur I dan II. Untuk Bakteri uji Salmonella typhi dihambat oleh isolat Bakteri III dan Jamur I. Untuk jamur uji Candida albicans dihambat oleh isolat Bakteri I, II, III dan Jamur I, II, III, IV. Dari hasil penelitian ini dapat disimpulkan bahwa aktivitas antibiotika terhadap mikroba uji dimana bakteri maupun jamur memperlihatkan daya hambat yang baik pada beberapa mikroba uji. Dengan standar persen antibiotika yang baik, tanah peternakan ayam ini berpotensi sebagai penghasil antibiotika yang baik.
\end{abstract}

Kata Kunci: Isolasi, Mikroba, Tanah peternakan ayam 


\section{PENDAHULUAN}

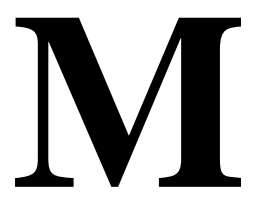

enurut Menteri Kesehatan Republik Indonesia (2011), Indonesia menduduki peringkat ke-8 dari 27 negara dengan beban tinggi kekebalan obat terhadap bakteri Multidrug Resistance (MDR) di dunia berdasarkan data World Health Organization (WHO) tahun 2009.

Menurut data dari European Centre for Disease Prevention and Control tahun 2012, selama beberapa tahun terakhir, telah terjadi peningkatan dalam resistensi antibiotika dan Multidrug Resistance (MDR) pada bakteri gram negatif seperti Klebsiella pneumonia dan Escherichio coli.

Guru Besar Farmakologi dari Universitas Gadjah Mada Iwan Dwiprahasto mengatakan penggunaan antibiotika tidak rasional dalam kasus infeksi saluran pernafasan akut mencapai 94 persen dan diare 87 persen. Sebaliknya untuk penyakit yang membutuhkan antibiotika hanya 20 persen yang mendapatkan antibiotika. Hasil penelitian lain yang dilakukan di 56 Puskesmas di 3 kawasan di Aceh tahun 2010 menunjukkan, 60 persen anak tidak membutuhkan, namun diresepkan antibiotika.

Tanah merupakan medium atau tempat tumbuhnya tanaman dengan sifatsifat tertentu, yang terjadi akibat dari pengaruh kombinasi faktor-faktor iklim, bahan induk, jasad hidup, bentuk wilayah dan lamanya waktu pembentukan (Yuliprianto, 2010:11).

Di dalam tanah banyak ditemukan ribuan jenis hewan dan mikroorganisme, dari yang berukuran sangat kecil (bakteri, fungi dan protozoa/invisibee mikro-biota) hingga yang berukuran sangat besar seperti cacing tanah, kutu, tikus, kaki seribu dan megafauna. Cacing tanah sering membentuk bagian utama biomassa hewan tanah dan dapat mempresentasikan hampir 50 persen biomassa hewan tanah di tanah padang rumput, dan hingga 60 persen tanah hutan. Cacing tanah dapat memperbaiki penyatuan bahan organik di bawah permukaan tanah, meningkatkan jumlah air tersimpan dalam agregat tanah, memperbaiki infiltrasi air, aerasi dan penetrasi akar dan meningkatkan aktivitas mikroorganisme. Partikel tanah yang digerakkan ke berbagai posisi oleh akar, cacing tanah, baik melalui siklus kering atau basah dan melalui kekuatan lain 
sehingga membentuk struktur tanah. Produksi kotoran mesofauna juga menyumbang pembentukan struktur tanah partikel dan ruang-ruang yang terbentuk di antara partikel (Yuliprianto, 2010:77-79).

Tanah merupakan campuran kompleks dengan komposisi sebagai berikut:

a) Materi Anorganik (45 \%) : Si, Al, Fe, $\mathrm{Ca}, \mathrm{Mg}, \mathrm{K}, \mathrm{Na}, \mathrm{P}$ dan lain-lain.

b) Materi Organik (5\%) : Karbohidrat, Protein, Lipid dan lain-lain.

c) Air $(25 \%)$ dan Udara $(25 \%) \mathrm{p}$

d) Organisme :Vertebrata, Invertebrata, Mikroba

Sebagian besar mikroba tumbuh dan berkembang biak di permukaan tanah, bahkan pada segumpal tanah dapat tumbuh beraneka ragam mikroorganisme. Untuk mengujikan dengan mikroorganisme pada partikel tanah, dapat diamati dengan mikroskop fluorosensi dimana kandungan mikroorganismenya akan berfluoresensi misalnya acridine orange. Sedangkan untuk mengamati mikroorganisme yang spesifik dalam partikel tanah dapat menggunakan pengujian dengan antibiotika. Untuk pengamatan Lebih jauh dapat menggunakan mikroskop elektron yang dapat memberikan informasi tentang morfologi dan jumlah sel pada permukaan partikel. Tanah merupakan salah satu habitat bagi mikroorganisme, dalam satu gram tanah terdapat jutaan bakteri, fungi, protozoa dan mikroorganisme lainnya. (Budiyanto 2012),

Tempat peternakan ayam kecamatan pattallasang Gowa merupakan tempat pemeliharaan dari ratusan peternakan ayam yang berada di daerah Gowa, dimana ratusan ayam ini tiap harinya mengeluarkan kotorannya yang dapat membantu kesuburan tanah, kemudian didukung dari segi tempat atau area peternakan yang tertutup dan tidak mendapatkan sinar matahari, Sehingga menjadikan tempat peternakan ayam menjadi lembab dan ini merupakan tempat yang sangat baik untuk pertumbuhan mikroba. Disamping itu komponen penyusun kotoran ayam itu sendiri merupakan zat organik maupun anorganik atau unsur hara yang merupakan sumber nutrisi bagi mikroorganisme. Dengan ini, penulis mengharapkan dari mikroorganisme tersebut terdapat mikroba penghasil antibiotika. 


\section{METODE PENELITIAN}

\section{Alat yang digunakan}

Autoklaf, cawan petri, enkas, gelas Erlenmeyer, gelas kimia, inkubator, Laminar Air Flow (LAF), lampu spritus, mikroskop, neraca O'haus, objek glas, ose lurus, ose bulat, oven, penangas air, tabung reaksi dan timbangan analitik.

\section{Bahan yang digunakan}

Air suling, Asam tatrat, Biakan murni (Escherichia coli, Bacillus subtilis, Pseudomonas aeruginosa, Salmonella typhosa, Staphylococcus aureus, Streptococcus mutans, Candida albicans dan Vibrio sp), etanol 96\%, Disk Blank, medium Glukosa Nutrient Agar (GNA), medium Glukosa Nutrient Broth (GNB), medium Maltose Yeast Broth (MYB), medium Nutrient Agar (NA), medium Nutrient Broth (NB), medium Potato Dekstrosa Agar (PDA).

\section{Mekanisme kerja}

1. Pengambilan sampel

Sampel tanah diambil didalam kandang dengan menggunakan sendok stainless steel secara aseptis pada kedalaman $15 \mathrm{~cm}$ dari permukaan tanah, sampel dimasukkan ke dalam botol steril, selanjutnya dibawah ke laboratorium.

2. Sterilisasi alat

a. Alat-alat yang diperlukan dicuci dengan deterjen kemudian dibilas dengan air suling.

b. Alat-alat dikeringkan dengan posisi terbalik di udara terbuka, kemudian setelah kering dibungkus dengan kertas perkamen.

c. Tabung reaksi dan gelas Erlenmeyer terlebih dahulu disumbat dengan kapas bersih

d. Alat-alat dari kaca di sterilkan di oven pada suhu $180^{\circ} \mathrm{C}$ selama 2 jam.

e. Alat-alat suntik dan alat-alat plastic lainnya (tidak tahan pemanasan tinggi) disterilkan dalam otoklaf pada suhu $121^{\circ} \mathrm{C}$ selama 15 menit dengan tekanan $2 \mathrm{~atm}$. 
f. Jarum ose disterilkan dengan api langsung.

3. Pembuatan Suspensi sampel

Sampel ditimbang 1 gram lalu dimasukkan ke dalam botol pengencer dan dicukupkan dengan air suling hingga $10 \mathrm{ml}$ (pengenceran $10^{-1}$ ). Suspensi sampel dari pengenceran $10^{-1}$ kemudian dibuat pengenceran $10^{-2}$, sampai pada pengenceran $10^{-5}$.

4. Pembiakan mikroba tanah

Suspensi sampel dari setiap pengenceran diambil $1 \mathrm{ml}$ secara aseptis. Kemudian dimasukkan kedalam cawan petri, kemudian ditambahkan Nutrien Agar (NA) untuk bakteri dan medium potato dextrose agar (PDA) untuk jamur lalu dihomogenkan. Diinkubasi pada suhu $37^{\circ} \mathrm{C}$ selama 1 x 24 jam untuk bakteri dan 3 x 24 jam untuk jamur.

5. Isolasi biakan mikroba tanah

Setelah diinkubasi, dilakukan pengamatan terhadap koloni yang tumbuh yang memperlihatkan adanya hambatan berupa daerah bening di sekelilingnya. Koloni ini selanjutnya akan diisolasi dan dipindahkan pada medium yang sama. Isolasi dilakukan berulang-ulang hingga diperoleh biakan murni yang hanya terdiri dari satu macam koloni. Biakan murni tersebut dipindahkan pada medium miring sebagai stok.

6. Fermentasi isolat murni

Biakan bakteri murni dan biakan jamur murni dimasukkan kedalam tabung reaksi kemudian ditambahkan MYB (maltose yeast brot) lalu di shaker selama 7 hari.

7. Peremajaan mikroba uji

Bakteri uji yang digunakan dalam penelitian ini meliputi (Bacillus subtilis, Escherichia coli, Pseudomonas aeruginosa, Salmonella tyhposa, Staphylococcus aureus, Staphylococcus epidermidis, Streptococcus mutans dan Vibrio sp). Bakteri yang berasal dari kultur koleksi Laboratorium Mikrobiologi Farmasi Fakultas Ilmu Kesehatan UIN Alauddin Makassar yang diremajakan dalam medium Nutrient Agar (NA) miring dan diinkubasi selama 1x 24 jam pada suhu $37^{\circ} \mathrm{C}$, sedangkan untuk jamur uji yang 
digunakan dalam penelitian ini adalah Candida albicans diambil satu ose lalu diinokulasikan pada suhu kamar selama 3 x 24 jam.

8. Pengujian aktivitas antibiotika

Suspensi mikroba uji sebanyak $1 \mathrm{ml}$ dimasukkan ke dalam $10 \mathrm{ml}$ medium NA untuk bakteri dan medium PDA untuk jamur kemudian dihomogenkan, kemudian dibiarkan hingga setengah memadat. Setelah itu diletakkan disk yang sudah direndam dengan filtrat hasil fermentasi secara aseptis. Diinkubasi pada suhu 370C selama 1x24 jam.

9. Pengamatan hasil uji

Daerah hambatan berupa zona bening disekitar disk yang berisi hasil fermentasi, setelah itu diukur dan dicatat zona hambat yang terbentuk.

\section{HASIL DAN PEMBAHASAN}

\section{A. Hasil Penelitian}

Tabel 1. Hasil Pengukuran Zona Hambat Fermentasi Isolat Bakteri Terhadap Mikroba Uji.

\begin{tabular}{|c|c|c|c|c|c|c|c|c|c|}
\hline \multirow{2}{*}{ NO } & \multirow{2}{*}{ Isolat } & \multicolumn{7}{|c|}{ Diameter Zona Hambatan (9 cm) } \\
\cline { 3 - 10 } & CA & EC & ST & PA & SM & SA & BS & Vsp \\
\hline 1. & $\begin{array}{c}\text { Bakteri } \\
\text { I }\end{array}$ & $2,3 \mathrm{~cm}$ & - & - & - & - & - & - & - \\
\hline 2. & $\begin{array}{c}\text { Bakteri } \\
\text { II }\end{array}$ & $2,2 \mathrm{~cm}$ & - & - & - & - & - & $0,7 \mathrm{~cm}$ & - \\
\hline 3. & $\begin{array}{c}\text { Bakteri } \\
\text { III }\end{array}$ & $2,4 \mathrm{~cm}$ & - & $0,9 \mathrm{~cm}$ & $0,8 \mathrm{~cm}$ & - & - & - & - \\
\hline
\end{tabular}

Tabel 2. Hasil Pengukuran Zona Hambat Fermentasi Isolat Jamur Terhadap Mikroba Uji.

\begin{tabular}{|c|c|c|c|c|c|c|c|c|c|}
\hline \multirow{2}{*}{ NO } & \multirow{2}{*}{ Isolat } & \multicolumn{7}{|c|}{ Diameter Zona Hambatan (9 cm) } \\
\cline { 3 - 10 } & CA & EC & ST & PA & SM & SA & BS & Vsp \\
\hline 1. & $\begin{array}{c}\text { Jamur } \\
\text { I }\end{array}$ & $2,5 \mathrm{~cm}$ & $0,8 \mathrm{~cm}$ & - & $0,8 \mathrm{~cm}$ & $0,9 \mathrm{~cm}$ & $0,7 \mathrm{~cm}$ & $0,8 \mathrm{~cm}$ & - \\
\hline 2. & $\begin{array}{c}\text { Jamur } \\
\text { II }\end{array}$ & $2 \mathrm{~cm}$ & $0,9 \mathrm{~cm}$ & - & $1 \mathrm{~cm}$ & - & - & - & - \\
\hline 3. & $\begin{array}{c}\text { Jamur } \\
\text { III }\end{array}$ & $2 \mathrm{~cm}$ & - & - & - & - & - & - & - \\
\hline 4 & $\begin{array}{c}\text { Jamur } \\
\text { IV }\end{array}$ & $2,3 \mathrm{~cm}$ & - & - & - & - & - & - & - \\
\hline
\end{tabular}


Keterangan:

$(-) \quad=$ Tidak memberikan daya hambat

$\mathrm{CA}=$ Candida albicans

$\mathrm{EC}=$ Escherichia coli

ST = Salmonella typhi

PA = Pseudomonas aeruginosa

$\mathrm{SM}=$ Streptococcus mutans

$\mathrm{SA}=$ Staphylococcus aureus

$\mathrm{Vsp}=$ Vibrio $\mathrm{sp}$

$\mathrm{BS}=$ Basillus subtilis

\section{B. Pembahasan}

Pada penelitian ini sampel yang diambil yaitu $15 \mathrm{~cm}$ diatas permukaan tanah peternakan ayam dan diambil pada bagian dalam kandang saja. Sampel ini dimasukkan kedalam botol steril kemudian dibawa ke laboratorium untuk diisolasi.

Hasil penelitian bakteri dan jamur dengan menggunakan media tumbuh NA(Natrium Agar) untuk bakteri dan PDA(Potato Dekstrosa) untuk jamur, dimana pada tahap pengenceran terdapat koloni yang menunjukkan adanya zona hambat yaitu pada bakteri dengan tingkat pengenceran $10^{-3}, 10^{-4}$, dan $10^{-5}$ sedangkan pada jamur yaitu dengan tingkat pengenceran $10^{-2}, 10^{-3}, 10^{-4}$, dan $10^{-5}$. Koloni ini kemudian di isolasi dengan metode kuadran/gores, dilakukan terus menerus sampai diperoleh koloni tunggal atau murni. Dari isolasi murni ini diperoleh 3 isolat murni dari bakteri yaitu bakteri I, bakteri II, dan bakteri III, sedangkan jamur diperoleh 4 isolat murni yaitu jamur I, jamur II, jamur III dan jamur IV. Tahap selanjutnya adalah uji aktivitas antibiotika isolat murni bakteri yang diperoleh terhadap mikroba uji.

Hasil pengamatan isolat bakteri pada tabel 1 menunjukkan bahwa :

- Bakteri uji CA(Candida albicans) Nampak adanya zona hambat dari isolat bakteri I, II, III dan IV dengan diameter masing-masing $23 \mathrm{~cm}, 22 \mathrm{~cm}$ dan $24 \mathrm{~cm}$.

- $\quad$ Bakteri uji EC(Escherichia coli) tidak nampak zona hambat dari isolat bakteri I, bakteri II dan bakteri III. 
- $\quad$ Bakteri uji ST(Salmonella typhi) tidak Nampak zona hambat pada isolat bakteri I dan bakteri II, hanya Nampak pada isolat bakteri III yaitu berdiameter $0,9 \mathrm{~cm}$.

- Bakteri uji PA(Pseudomonas aureus) tidak Nampak zona hambat pada isolat bakteri I dan bakteri II, hanya Nampak pada isolat bakteri III yaitu berdiameter $0,8 \mathrm{~cm}$.

- $\quad$ Bakteri uji SM( Streptococcus mutans) ) tidak nampak zona hambat dari isolat bakteri I, bakteri II dan bakteri III.

- Bakteri uji SA(Staphylococcus aureus) juga tidak Nampak zona hambat pada isolat bakteri I dan bakteri II, hanya Nampak pada isolat bakteri III yaitu berdiameter $1,1 \mathrm{~cm}$.

- $\quad$ Bakteri uji Vsp(Vibrio $s p$ ) tidak nampak zona hambat dari isolat bakteri I, bakteri II dan bakteri III..

- $\quad$ Bakteri uji BS(Basillus subtilis) nampak adanya zona hambat dari isolat bakteri II dengan diameter $0,9 \mathrm{~cm}$, dan untuk isolat bakteri I dan III tidak Nampak adanya zona hambat.

Hasil pengamatan isolat jamur pada tabel 2 menunjukkan bahwa :

- $\quad$ Bakteri uji CA(Candida albicans) Nampak adanya zona hambat dari isolat jamur I, II, III dan IV dengan diameter masing-masing $25 \mathrm{~cm}, 2 \mathrm{~cm}, 2 \mathrm{~cm}$ dan $23 \mathrm{~cm}$.

- $\quad$ Bakteri uji EC(Escherichia coli) Nampak zona hambat dari isolat jamur I dengan diameter $0,8 \mathrm{~cm}$ dan isolat jamur II dengan diameter $0,9 \mathrm{~cm}$, sedangkan isolat jamur III dan IV tidak nampak adanya zona hambat yang diberikan.

- $\quad$ Bakteri uji ST(Salmonella typhi) tidak Nampak adanya zona hambat dari isolat jamur I, isolat jamur II, isolat jamur III dan isolat jamur IV.

- $\quad$ Bakteri uji PA(pseudomonas aurigenosa) Nampak adanya zona hambat dari isolat jamur I dan isolat jamur II dengan diameter masing-masing $0,8 \mathrm{~cm}$ dan $1 \mathrm{~cm}$, sedangkan pada isolat jamur III dan isolat jamur IV tidak Nampak adanya zona hambat yang diberikan. 
- $\quad$ Bakteri uji SM(Streptococcus mutans) Nampak adanya zona hambat dari isolat jamur I dengan diameter $0,9 \mathrm{~cm}$, sedangkan pada isolat jamur I, isolat jamur II dan isolat jamur III tidak Nampak adanya zona hambat yang diberikan.

- Bakteri uji SA(Staphylococcus aureus ) hanya Nampak adanya zona hambat dari isolat jamur I dengan diameter $0,7 \mathrm{~cm}$, sedangkan pada isolat II, III dan IV tidak Nampak adanya zona hambat yang diberikan.

- $\quad$ Bakteri uji Vsp(Vibrio sp) tidak Nampak adanya zona hambat yang diberikan isolat jamur I, isolat jamur II, isolat jamur III dan isolat jamur IV.

- $\quad$ Bakteri uji BS(Basillus subtilis) Nampak zona hambat dari isolat jamur I dengan diameter $0,8 \mathrm{~cm}$, sedangkan isolat jamur II, isolat jamur III dan isolat jamur IV tidak nampak adanya zona hambat yang diberikan.

Zona hambat yang dihasil oleh setiap isolat baik jamur maupun bakteri menunjukkan bahwa isolat tersebut mengandung senyawa antibiotika yang dapat menghambat pertumbuhan mikroorganisme lain dengan memberikan zona hambat.

Menurut clinical and laboratory standards institute ( CLSI) bahwa satandar zona hambat yaitu isolat bakteri $\mathrm{EC}($ Escherichia coli) adalah $2 \mathrm{~cm}$, isolat bakteri SA $2 \mathrm{~cm}$, isolat jamur CA(Candida albicans) $2,5 \mathrm{~cm}$.

Dari hasil penelitian menunjukkan bahwa mikroba pada tanah peternakan ayam kecamatan pattallassang memberikan zona hambat terutama pada bakteri uji CA(Candida albicans). Hal ini menunjukkan bahwa sampel tanah ini berpotensi sebagai mikroba penghasil antibiotika.

Faktor yang mempengaruhi tingkat kesuksesan tanah peternakan ayam dalam menghasilkan mikroorganisme penghasil antibiotika yang baik adalah Jumlah dan macam zat hara yang mencukupi, tingkatan kelembaban yang sesuai, suhu, $\mathrm{pH}$ serta perlakuan pada tanah seperti penambahan pupuk atau banjir yang menyebabkan peningkatan jumlah mikroorganisme.

Allah sangat menghargai bentuk-bentuk pengobatan yang bersumber dari ilmu pengetahuan, penelitian, eksperimen ilmiah. Tidaklah Allah menciptakan sesuatu dengan sia-sia, sekecil apapun itu semisal mikroba atau lebih sederhana 
dari itu. Salah satu bukti nyata dari ayat diatas yang menerangkan bahwa sekecil apapun makhluk itu pasti memiliki manfaat sehingga penelitian ini dilakukan untuk mencari senyawa antibiotika yang berasal dari mikroba-mikroba yang ada pada tanah sehingga nantinya diharapkan dapat bermanfaat baik dibidang ilmu pengetahuan maupun dibidang kesehatan.

\section{PENUTUP}

\section{A. Kesimpulan}

Dari hasil pengamatan yang telah dilakukan pada isolasi mikroba penghasil antibiotika dari tanah peternakan ayam kecamatan pattallassang kabupaten Gowa dapat disimpulkan bahwa :

1. Dari hasil isolasi mikroba yang dilakukan dapat diperoleh hasil dengan adanya zona hambat disekeliling koloni yaitu 3 isolat bakteri dan 4 isolat jamur yang berpotensi sebagai antibiotika.

2. Dari hasil pengujian aktivitas antibiotika terhadap mikroba uji dimana bakteri maupun jamur memperlihatkan daya hambat yang baik pada beberapa mikroba uji. Dengan standar zona hambat yang sudah ditentukan, tanah peternakan ayam ini berpotensi sebagai penghasil antibiotika yang baik.

\section{B. Saran}

Penelitian ini sebatas sampai pada isolasi mikroba yang menghasilkan antibiotika saja dan belum sampai sespesifik mungkin. Untuk itu diharapkan agar melakukan penelitian lebih lanjut mengenai uji morfologi baik mikroskopik maupun makroskopik, serta uji-uji selanjutnya untuk lebih spesifik.

\section{KEPUSTAKAAN}

Abimbola, I. O. (2013). Knowledge and practices in the use of antibiotics among a group of Nigerian university students. Nigerian University.

Departemen pendidikan nasional. (2010). Kamus besar bahasa Indonesia. Jakarta : PT. Gramedia Pustaka Umum. 
Hardjowigeno, S. (2011). Ilmu Tanah. Jakarta : Akademik Presindo.

Harti A, S . (2012). Dasar-dasar mikrobiologi kesehatan. Bandung : Tri Jaya.

Irianto koes. (2013). Mikrobiologi Medis medical mikrobiologi. Bandung: Alfabeta.

Junaidi. W. (2011). “Mikroorganisme penghasil antibiotik bakteri. Lampung.

Krisno, M. (2011). Peranan Mikroba. Jakarta : Plames.

Putri. (2011). Mikrobiologi. Yogyakarta : PT Intra Jaya.

Singh A. P and Sanjay Mishra. (2013). Isolation and Biochemical Characterization of Antibiotic Producing Microorganism from Waste Soil Samples of Certain Industrial areas of India. India : IFTM University.

Suwandi , U. (2011). Mikroorganisme Penghasil Antibiotik”. Bandung : Kalbe.

Wahyu, L. (2010). Mikroorganisme. Jakarta : Gramedia.

Yulipriyanto. (2010). Biologi Tanah dan Strategi Pengelolaannya.Yogyakarta : Graha Ilmu. 